\title{
CANTILLON AND THE RISE OF ANTI-MERCANTILISM
}

\author{
MARK THORNTON*
}

Resumen: En este trabajo se pretende demostrar que Cantillon formó parte tanto del pensamiento como del movimiento antimercantilista de su época, influyendo en gran medida en el cambio de opinión en contra del mercantilismo que se fue fraguando de 1720 a 1734.

Clasificación JEL: B110, B31, N010.

Abstract: This article places Cantillon at the center of anti-mercantilist thought and the anti-mercantilist movements in London and Paris between the time of the Bubbles of 1720 and his murder in 1734 and it places his ideas at the turning point between the eras of mercantilism and antimercantilism.

JEL classification: B110, B31, N010.

"It seems to me that there is a connection between physiocracy and anti-mercantilism, or at any rate between Boisguilbert (1646-1714) and Quesnay

(1694-1774), though it is not easy to say just what this connection was.»

Martin Wolfe ${ }^{1}$

«In itself Cantillon's (168?-1734?) was a contribution of real significance, and it would be difficult to find a more incisive prophet of nineteenth-century liberalism.»

Robert B. Ekelund, Jr. and Robert F. Hébert ${ }^{2}$

\footnotetext{
* Dr. Mark Thorntorn, Senior Fellow, Ludwig von Mises Institute, mthornton@mises.org

${ }^{1}$ Martin Wolfe, «French Views on Wealth and Taxes from the Middle Ages to the Old Regime,» Journal of Economic History 26 (1966): 466-483.

2 Robert B. Ekelund, Jr. and Robert F. Hébert. A History of Economic Theory and Method (New York: McGraw-Hill, 1975): 44.
}

Procesos de Mercado: Revista Europea de Economía Política Vol. VI, n. ${ }^{\circ}$, Primavera 2009, pp. 13 a 42 


\section{I \\ INTRODUCTION}

Richard Cantillon (168?-1734?) the Irish banker who made his fortune in the Mississippi Bubble has often been celebrated as the first theoretical economist. The list of his contributions stretches from economic methodology, price theory, human capital theory and wages to the circular flow mechanism, pricespecie flow mechanism, and business cycle theory. He integrated population theory, location theory, capital asset pricing, and a sophisticated monetary theory throughout his Essai sur la Nature du Commerce en Général (circa 1730, hereafter Essai). Only recently has Cantillon been credited with the discovery of the concepts of opportunity cost and possibly the first construction of the invisible hand. ${ }^{3}$

Not surprisingly he has been claimed to be the forerunner of various schools of economic thought including Austrian, Classical, Neoclassical, and Physiocrat schools, and is even considered a forerunner of Walrasian economics. Based on his class analysis and surplus value analysis he might even be claimed by the Marxists. However, the dominant claim has long been that Cantillon was a Mercantilist because he was a merchant banker, who wrote in the Mercantilist era, and most importantly he appeared to exhibit sympathies for mercantilist economic policies. However, these claims have always been tentative or qualified because with Cantillon it is not the typical matter of minor differences with the loose canons of mercantilism - he had clear theoretical differences with some of the major tenets of mercantilist doctrine. In a recent reexamination of the evidence, Cantillon's statements that have been used to justify the classification of mercantilism were found to be problematic when placed into the proper textual and historical context.

The claim made and defended here is that Cantillon is possibly best viewed as an anti-mercantilist. It is certainly true that the mercantilists were not an organized «school» and that the concept

${ }^{3}$ Mark Thornton, «Richard Cantillon and the Discovery of Opportunity Cost», History of Political Economy, vol. 39, n.ำ 1, Spring 2007, pp. 97-119. 
of mercantilism has been nearly muddled beyond scientific usefulness. It is also true that while the concept of anti-mercantilism has been used, for example, to describe Adam Smith, it has not been widely used or deeply examined. These difficulties however can be avoided in the present context to allow us to demonstrate that Cantillon can be contrasted with mercantilism and placed in the anti-mercantilist camp. Here mercantilism is represented by the writings of prominent English mercantilists and by the various economic policies employed by France and England in their efforts to exploit their colonial empires: colonialism, war, national debt, the manipulation of money and banking, the regulation of trade and industry, and support for special interests. This definition of mercantilism represents the perspective and interests of those in political power, the ruling elites, financial powers, and the captains of industry. This is a perspective that is nominally pro-capitalist, but in reality is interventionist and describes a system of exploitation that has some similarities to the rent-seeking view of mercantilism. This is the classic «insider» perspective.

Anti-mercantilism is even more poorly defined because it is simply the opposition to mercantilism. Naturally we should expect some form of opposition movement to emerge to face the dominating forces of seventeenth and eighteenth century mercantilism. Anti-mercantilism is thus the ideas of those who were opposed to the ruling elites and in particular the «moneyed interests.» The ideas and ideology of this opposition movement took a giant leap forward between the times of Fénelon, Vauban, and Boisguilbert and those of Montesquieu's Spirit of the Laws, David Hume, and the Physiocrats. This was the time of Cantillon, the birth of economic theory, and the beginnings of Liberalism.

To sustain this claim four types of evidence will be presented. First, Cantillon's economics will be examined to establish his general economic views as they relate to mercantilism and government intervention in the economy. Second, Cantillon's comments in the Essai regarding other economic writers are examined to determine if they indicate support or opposition to mercantilism. Third, Cantillon's «circle» will be sketched out - who he knew and their ideas. Would they be considered mercantilists 
and insiders, or would they be considered anti-mercantilists and outsiders? Finally a short review of Cantillon's influence on subsequent economic writers will be provided. This entire body of evidence places Cantillon at the center of anti-mercantilist thought and the anti-mercantilist movements in London and Paris between the time of the Bubbles of 1720 and his murder in 1734 and it places his ideas at the turning point between the eras of mercantilism and anti-mercantilism.

\section{II}

\section{POLICY ESPOUSAL}

What were long thought to have been Cantillon's mercantilist policy sympathies regarding money, the balance of trade, and regulation of industry have recently been shown to be far less justified than previously thought. When this handful of selected quotes is placed into the proper historical and textual context they can even take on the possibility of being arguments against mercantilism and for a more laissez faire economy. For example, Cantillon explained several marginal advantages of the flow of money from a positive balance of trade, but to counter the mercantilists he also warned that such advantages could not last and would be reversed bringing negative consequences. He also made a cogent argument directly against the mercantilist position that an increased flow of money would reduce the interest rate, by showing that the impact on the interest rate would depend on who received the flow. With all the old claims regarding Cantillon's supposed mercantilism now answered, we move on to the question of whether he was really an antimercantilist.

In order to get a comprehensive picture of Cantillon's views let us now take an overview of his theoretical and policy convictions. Cantillon viewed wealth as the ability to consume, not as a function of money. He held that society was the result of property rights and the state was a creature of war and conquest. Settlements are based on trade and the division of labor. Skilled workers are paid more than unskilled workers. 
Higher skilled workers, those that face higher risks on the job, and those jobs that require trustworthiness all earn higher wages, but all skilled jobs are limited by the demand for their products. The supply of skilled workers is also limited by the opportunity cost of training workers. The relative prices of resources - which have a natural inequality - are found only through the use of money in exchange.

For Cantillon, the standard of living is dependent on the interdependent relationship between labor and property owners. The production and distribution of goods is done by entrepreneurs including farmers, manufacturers, artisans, retailers, etc., who face risk because of fluctuations of supply and demand, while large property and money owners are independent and live on the rents of their land or the interest on their capital. Consumer demand causes changes in markets prices and determines how resources will be put to use. Demand even determines population, which does not follow any kind of Malthusian formula. The wealth of a nation is a function of savings and the ability of the labor force to produce high quality manufactured goods at competitive prices and is reduced by unemployment and waste. In other words, the real economy can be described as a self-regulating system.

Cantillon provided a logical reconstruction of how the gold and silver coin standard emerged as money in a way similar to Carl Menger who showed that money emerged spontaneously through the self-interested actions of individuals in a competitive environment. Money originated in the marketplace where no single person designed a universal medium of exchange, and no government compulsion was necessary to bring about the transition from barter to a monetized economy where improvements in the use of money are introduced over time. Gold and silver are money because of utility, not consent.

In part two of the Essai, Cantillon began by noting the natural inequality of all resources and then explained that money is the medium of exchange that helps us overcome the problem of barter with market prices emerging from the bargaining between buyers and sellers, while some prices are affected by, for example, international trade. The quantity of money is not equal to the 
amount of goods; money is just a medium of exchange that circulates. Cantillon considered this important «if it prevents the governors of states from forming extravagant ideas of the amount of money in circulation. $\rangle^{4}$ In fact, Cantillon demonstrated that the lack of money in rural areas was the result of money being sent to the capital to pay taxes to government and rents to absentee landowners. Cantillon's tax reform proposal - a tax on land rents- put him firmly in the French anti-mercantilist tradition between Boisguilbert and Vauban (who argued for a uniform income tax) and the Physiocrats and Turgot (who advocated a uniform tax on land rent) to reform the corrupt tax system.

Cantillon easily recognized that increasing the supply of money increased prices and rents while less money reduced them. However, he went beyond the simple quantity theory to show the mercantilist's error by demonstrating that the increased money resulted in benefits for some, but that eventually - via increased consumption and higher prices - there would be widespread costs and losses. For him real prosperity was the result of the production of high-valued goods, low-cost trade, and savings. Demonstrating the non-neutrality of money, Cantillon also showed that money has microeconomic effects that cause redistributions of wealth. Even under the best conditions his analysis showed that an increase in money will result in a cycle of abundance followed by poverty via the pricespecie flow mechanism. The only possible exception is if the prince were to deposit large sums of money into his treasury for the purpose of defending the nation in time of war. He noted that even an empire that extracts a flow of money from its colonies will eventually decline.

Interest rate theory is one of the clearest examples of Cantillon's opposition to mercantilism. Here the interest rate is a function of supply and demand and interest rates on loans are based on the risks involved. The bulk of his analysis is devoted to the folly

\footnotetext{
${ }^{4}$ Cantillon (174-5/133/55). The first page reference is to the original French edition in Higgs. The second page number is to Higgs's English translation and the third page reference is to the recent Brewer edition.
} 
of usury laws. He began by noting that entrepreneurs can produce using their own capital, borrowing money, or buying inputs to be paid at a latter date. In the latter case interest is built into the prices of resources. Whether interest is implicit, explicit, or "profit» in the case of the self-financed entrepreneur, there is an opportunity cost of capital which must be paid (including risk) in order for loans to be available. Cantillon asked: why should some forms of financing business receive preference over another? Usury laws that attempt to lower the interest rate will only harm trade and lead to secret bargains and even higher rates. He also exploded the mercantilist's notion that more money leads to lower interest rates by showing that an expansion of the money supply can coexist with higher rates and that a lower supply of money can coexist with lower rates, it all depends on who gets the new money. Big government, a large national debt and warfare raises interest rates, while peace and paying off the national debt lowers interest rates. This, of course, shows support for some of the core beliefs of antimercantilism.

In chapter one of part three Cantillon argued that France and Spain should adopt policies similar to the British Navigation Acts. This is an endorsement of mercantilist policy, but he clearly showed that this support is not based on any economy of the Acts directly, but only indirectly in providing a merchant marine that can be converted to military purposes in times of war. Private ships and sailors were the backbone of a nation's naval force and they did the most damage to the opposition's commerce and were largely defensive in nature. Thus he concluded:

I will limit myself to saying that in countries where trade does not regularly support a considerable number of ships and sailors it is almost impossible for the Prince to maintain a flourishing navy without such expense as would be capable by itself of ruining the treasure(y) of his State. ${ }^{5}$

\footnotetext{
${ }^{5}$ Cantillon (322/243/99).
} 
This is the same position later adopted by the Scottish antimercantilist, Adam Smith.

Cantillon then explained banking by which he meant the facilitation of intra and international trade by means of bills of exchange. This process was a mystery to those who were not familiar with it, involving exchange rates, discounts and premiums, and mysterious movements of gold. However, Cantillon explained the process as a series of competitive and beneficial exchanges. He also noted that the prohibition on exporting gold (e.g. in England and Portugal) provided no advantage and was actually counterproductive to those nations that enacted them. He concluded:

I do not know whether I have succeeded in making these reasons clear to those who have not idea of trade. I know that for those who have practical knowledge of it nothing is easier to understand, and that they are rightly astonished that those who govern states and administer the finances of great kingdoms have so little knowledge of the nature of exchanges as to forbid the export of bullion and specie of gold and silver. ${ }^{6}$

The relative prices of precious metals (e.g. gold and silver) are based on the opportunity cost of producing them and their relative supply and demand conditions in the market. «Still I do not think that one can imagine any rule but this to arrive at it. At least we know that in practice it is the one which decides, as in the price and value of everything else. ${ }^{7}$ Cantillon argued that the exchange ratio should be based on market prices, not edict or tradition and thus he attacked bi-metallism and supported multi-market metallism, or what now is referred to as parallel standards. Sir Isaac Newton, the famous scientist, was actually a classic «insider» serving in Parliament, the Royal Society, and was master of the London mint. Cantillon attacked Newton for his monetary reforms which were based on tradition rather than market prices. Newton's solution did not solve the problem and

\footnotetext{
6 Cantillon (354-5/267/108)

7 Cantillon (369/279/112).
} 
made matters even worse for those engaged in international trade. ${ }^{8}$ Cantillon noted that in Newton's response to Cantillon's suggestions for reform, Newton «sacrificed substance to appearances.» ${ }^{9}$

Next Cantillon attacked the monetary manipulations in France (circa 1714) whereby the King ordered that the nominal value of money to be reduced by twenty percent over a twenty month period. This encouraged people to pay off their loans and for businesses to buy large inventories of goods while the King and «enlightened people» hoarded and borrowed as much money as possible. At the end of the period money was revalued to the original level and new coins were issued. This was a great benefit to the King but it sent the market into «convulsions» and resulted in widespread bankruptcies, and according to Cantillon «France is all round the dupe of these operations.» ${ }^{10} \mathrm{He}$ then recounted several historical episodes of monetary manipulation by government and he concluded «the change in the nominal value of money has at all times been the effect of some disaster or scarcity in the State, or of the ambition of some Prince or individual.»11 The general overall anti-mercantilist lesson here is that the state need not and should not intervene in money.

Finally Cantillon concluded the Essai on the subject of banking. Cantillon's first goal was to explain the utility of banking because some mercantilists believed that banks drew money out of the economy and hoarded it. His second goal was to explain that central banking was responsible for the Mississippi and South Sea bubbles. He began by showing that bankers who take in large long-term savings deposits and who are given advanced notice of withdrawals can lend out most of deposits and charge interest on the loans. This is best described as a savings bank. The most common form of banker takes in deposits of peoples' income and redeems those deposits when expenditures are made.

\footnotetext{
8 Findlay Shirras and J.H. Craig, "Sir Isaac Newton and the Currency,» The Economic Journal 55 (1945): 217-241.

9 Cantillon $(377 / 283 / 114)$.

10 Cantillon $(389 / 293 / 118)$.

11 Cantillon (393-4/297/119).
} 
This type of banker must keep most of the deposits on reserve rather than lending them out or «be ruined in credit if they fail for one instant to pay their notes on their first presentation.» ${ }^{12}$ Commercial banks must also hold large reserves, because depositors make frequent large withdrawals. The utility of banking therefore is that it increases the circulation of money, it does not hoard it, but there are clear limits on the amount of money that can be created.

Central banks can also add to the money in circulation, but Cantillon reminded his readers that he had already established that «there are cases where it is better for the welfare of a state to retard the circulation than it accelerate it.» ${ }^{13} \mathrm{He}$ noted that the Bank of Venice caused «discredit» and «disorder» and ultimately there is no real advantage in central banks, only the potential for great macroeconomic disorder:

And when money circulates there in greater abundance than among its neighbors a national bank does more harm than good. An abundance of fictitious and imaginary money causes the same disadvantages as an increase in real money in circulation, by raising the price of land and labor, or by making works and manufactures more expensive at the risk of subsequent loss. But this furtive abundance vanishes at the first gust of discredit and precipitates disorder. ${ }^{14}$

Cantillon found that central banks are not necessary for the collection of taxes and he showed that government manipulation of money and credit had caused economic disorder as far back in history as the Roman Empire.

Though I consider a general bank is in reality of very little solid service in a great state I allow that there are circumstances in which a bank may have effects which seem astonishing. ${ }^{15}$

\footnotetext{
12 Cantillon (401/303/122).

13 Cantillon (408/307/124).

14 Cantillon (413/311/125).

15 Cantillon (418/315/127).
} 
When nations such as England and France became deep in debt due to years of warfare they looked to financial experiments - which were essentially rudimentary central banks - to solve their problems. In 1720 the fictitious money issued by these central banks created bubbles in «pestilential stocks» which led to extravagance and this eventually «broke up all the systems.» Cantillon concluded that central banks cause "surprising results» and that «the help of banks and credit of this kind is much smaller and less solid than is generally supposed. Silver alone is the true sinews of circulation.» 16

Cantillon warned in several places against a large national debt and that the Prince should be frugal and even take money out of circulation. The great disorder brought on by central banks and their attempts to pay off the national debt was one consequence of not following this advice. More generally this process of endemic corruption is one that Cantillon learned of first hand while working in the British Paymasters Office during the War of Spanish Succession. On the surface there is luxury and extravagance while behind the scene there is corruption in government procurement. Cantillon recounted that the Bank of England was only saved by the deception of the public while in France the scheme imploded.

It is then undoubted that a bank with the complicity of a minister is able to raise and support the price of public stock and to lower the rate of interest in the state at the pleasure of this minister when steps are taken discreetly, and thus pay off the state debt. But these refinements which open the door to making large fortunes are rarely carried out for the sole advantage of the state, and those who take part in them are generally corrupted. ${ }^{17}$

Cantillon's theory is that the government causes the business cycle and that in the absence of such government intervention the macro economy is self regulating in the sense of Say's Law.

\footnotetext{
16 Cantillon (423/319/128).

17 Cantillon (429/323/130).
} 
In canvassing the Essai one can find many lessons, but the general lessons are three. First, markets work and are self regulating. Second, government intervention is unnecessary to make markets work. Third, government interventions have unintended consequences that cause disturbances, disruptions, and embarrassments in the economy, or what we might today call unintended consequences. Cantillon essentially critiqued the primary tenets of mercantilism and found them untrue, destructive, or wanting of some economic rationale.

III

\section{KNOWN INFLUENCES}

Scholars such as Tony Aspromourgos and Anthony Brewer have examined the Essai for possible influences from other writers. ${ }^{18}$ The evidence suggests that Cantillon was widely read on a variety of subjects including economics, history, and population. He was no doubt influenced by several writers in economics, but for our purposes we can pass over this large body of work that scholars have offered on this subject and instead concentrate on the direct evidence from the Essai itself where Cantillon references certain writers and their work. This evidence provides a clear clue about Cantillon's views on mercantilism.

The first person cited in the Essai is Sir Edmund Halley the famous astronomer. In addition to the comet, Halley is also noteworthy for encouraging Newton to publish his groundbreaking work in mathematics. Cantillon referenced Halley's lesser known, but important work An Estimate of the Degrees of the Mortality of Mankind. ${ }^{19}$ This work permitted the British government to sell life insurance at a sustainable price. Cantillon used Halley's work

18 Tony Aspromourgos, On the Origins of Classical Economics: Distribution and Value from William Petty to Adam Smith (New York: Routledge, 1996) and Anthony Brewer, Richard Cantillon: Pioneer in Economic Theory (New York: Routledge, 1992).

19 Edmund Halley, An Estimate of the Degrees of the Mortality of Mankind, drawn from curious Tables of the Births and Funerals at the City of Breslaw; with an Attempt to ascertain the Price of Annuities upon Lives. Philosophical Transactions 196 (January 1692/ 93): 579-610. 
in part to construct his famous estimate of the par between land and labor - referenced by Adam Smith in the Wealth of Nationsthat the value of menial labor must correspond to at least twice the level of subsistence to support a sufficient number of children so that labor can perpetuate itself. The amount of land that corresponds to labor is double the amount of labor's subsistence in order to perpetuate the current quantity of labor. Cantillon's investigation revealed that his estimate was only a theoretical starting point and that there can be no fixed relationship, or par in the real world.

Cantillon concluded his investigation by noting that the value of labor will depend on circumstances of time and place and that only monetary exchange can provide an approximate guide. Cantillon ended chapter eleven with a stinging attack on Petty, Locke, and Davenant «and all other English authors who have written on the subject.»

Sir Wm. Petty, in a little manuscript of the year 1685 considers this par, or equation between land and labor as the most important consideration of Political Arithmetic, but the research which he has made into it in passing is fanciful and remote from natural laws, because he has attached himself not to causes and principles but only to effects, as Mr. Locke, Mr. Davenant and all the other English authors who have written on this subject have done after him. ${ }^{20}$

This is important because Petty, Locke, and Davenant were all important mercantilist writers and all were classic «insiders.» Cantillon ridiculed Petty's notion of the importance of par value and belittled his research as fanciful, and even attacked his methodology (i.e. empiricism) and then extended this criticism to Locke, Davenant, and «all other English authors who have written on this subject.» Thus Cantillon assailed the subject, content, and method of the English mercantilists.

Halley reappeared in chapter fifteen on the subject of population with Cantillon commenting again on his work on mortality and

${ }^{20}$ Cantillon (54-5/43/21). 
life expectancy. Halley claimed that not one in six fertile females had a child in a given year when the number should have been four out of six females. Given Halley's proposed remedies to increase population - which included subsidies, tax breaks, welfare, and that «Celibacy ought to be discouraged as, by extraordinary Taxing and Military Service»— suggests that Halley himself might have mercantilist sympathies on the subject of population, but the important point is that Cantillon used Halley's evidence to support his view of population against the view of the mercantilists.

Sir Wm. Petty, and after him Mr. Davenant, Inspector of the Customs in England, seem to depart from nature when they try to estimate the propagation of the race by progressive generations from Adam, the first Father. Their calculations seem to be purely imaginary and drawn up at hazard. ${ }^{21}$

Cantillon's own view on population is that it is based on economics and choice and most importantly on the choices of property owners. He attacked the view of the mercantilists, along with that of a Mr. King, who was later cited by Malthus, who projected population backwards and forwards in history using estimated current growth rates. Cantillon attacked this protoMalthusian approach to population by citing instances where population declined over time and then he made the correct prediction that the population in the American colonies where «men multiply like mice in a barn» will become relatively more numerous in three generation than England will in thirty.

Petty made one final appearance in chapter three of part two where Cantillon estimated the amount of money in circulation. Here he basically agreed with Petty that the amount of money in circulation was about ten percent of the value of agricultural production. However, Cantillon attacked his casual empiricism and his concern for estimating the tax base. Cantillon preferred his own theoretically derived estimate and was primarily

${ }^{21}$ Cantillon (108-11/83/37). 
interested in determining the amount of money in circulation especially «if it prevents the governors of states from forming extravagant ideas of the amount of money in circulation.» Moreover Cantillon's more generally applicable method of calculating money in circulation was also related to his suggestion for tax reform - a uniform tax on land rents. His proposal would be adopted by latter French anti-mercantilists, such as Turgot.

John Locke came under scrutiny and served as the foil for Cantillon's groundbreaking analysis of money and prices. At the end of part one Cantillon criticized Locke's notion that gold and silver are money by the consent of mankind and Cantillon noted that this is only true in the sense that the same consent determines the daily prices of all other goods - money is not based on an imaginary value. Money has an opportunity cost of land and labor which must be taken into account. In the first chapter of part two Cantillon criticized Locke and «all the English writers on this subject» for their simple quantity theory of money where the price of a good is based on the relative scarcity or abundance of the good and money because they neglected, for example, the impact of intermarket trade. Then in chapter six he reiterated his criticism while laying out his famous contribution now known as Cantillon or first-round effects, where he more fully explored the relationship of microeconomics to macroeconomics through monetary theory. Cantillon noted that Locke clearly saw «that the abundance of money makes every thing dear, but he has not considered how it does so.» 22 Cantillon explained the processes and their implications, so as to go beyond rising and falling prices to their causes and effects.

As Cantillon's criticism of Newton was already fully described in the first section there are only two authors left to detail. In chapter five of part two Cantillon explained the inequality of money in circulation within a state with particular reference to the lack of money and economic development in rural France. At the end of the chapter he referred to Vauban's plan to reform taxation in France. Although Vauban is most famous as a military

22 Cantillon (213/161/67). 
engineer, he was also a vocal opponent of Colbert mercantilism and he condemned the repeal of the edict of Nantes on economic grounds just as Cantillon did. Vauban had fallen out of favor later in life due to his stinging anti-establishment economic critiques and thus he can be labeled an outsider. Cantillon politely disagreed with Vauban's tax reform proposal that called for a ten percent general income tax to replace all existing taxes. ${ }^{23}$ Cantillon suggested instead his own idea for a proportional tax on land rents. He clearly appeared to agree with Vauban on the need for reform, simplification, and that the tax burden needed to be shifted, but he noted that Vauban's approach was both unworkable and unfair. Instead Cantillon believed that taxation should be collected only from property owners, rather than the working class. The state after all was protecting the owners' property rights and it would be much easier to collect taxes from the smaller number of property owners. In addition, property owners would provide a better check on the demands of government.

Cantillon mentioned a Mr. Boizard on the technology of refining of silver and one final author who is not mentioned in the Essai by name. Cantillon reported that he had read État de la France and he politely chides the author: «I think he has mistaken the effect for the cause» regarding the decline of rents in France. ${ }^{24}$ Cantillon's English translator Henry Higgs half-heartedly attributed the authorship of the book to Boulainvilliers. We now know that the reference is actually to Boisguilbert thanks to the work of Benítez-Rochel and Robles-Teigeiro who reported both textual evidence and evidence of influence and concluded that Boisguilbert was the most important influence on Cantillon's development of the circular-flow nature of the economy. ${ }^{25}$ Boisguilbert was a vocal proponent of laissez faire and opponent of mercantilism. He wrote extensively on the virtues and

23 Projet de dixme royale (Project for a royal tithe, 1707)

24 Cantillon (248/187/77).

25 José J. Benítez-Rochel and Luis Robles-Teigeiro, «The foundations of the Tableau Économique in Boisguilbert and Cantillon,» European Journal of the History of Economic Thought 10 (2003): 231-248. 
harmony of the market and trade and the counterproductive nature of government intervention and he endorsed Vauban's proposal for a single ten percent tax on all incomes. ${ }^{26}$ The views of Boisguilbert would seem to have rubbed off onto Cantillon even if the latter constructed the theoretical superstructure to support those views. Thus there seems to be a progression of ideas in France from the first generation of anti-mercantilists, such as Vauban and Boisguilbert, who Rothkrug labeled "Christian agrarians, " to Cantillon's generation of the first half of the eighteenth century. ${ }^{27}$

Cantillon left us with the names of only seven men who wrote on economic issues and one unnamed author, Boisguilbert, and one unidentified minister, who was probably John Law. Halley and Boizard were merely technical references. The views of Davenant, Locke, Petty «and all other English authors who have written on this subject» are ridiculed and their methods are condemned on the subjects of the par between land and labor, population, and money. Newton is criticized for his failed reforms at the Mint. These four along with King and Halley were all classic insiders holding prestigious positions in the British government. Halley and Newton are today considered great scientists, but both held prestigious positions within government. In contrast, the two Frenchmen Boisguilbert and Vauban met with only minor polite criticism from Cantillon and some indication of sympathy for their anti-mercantilist work. Both were outspoken critics of the French regime who attacked mercantilism and whose work was censured and suppressed. This examination of all the references in the Essai strongly suggests support for the contention that Cantillon was of anti-mercantilist sympathies.

${ }^{26}$ Stephen L. McDonald, «Boisguilbert: A Neglected Precursor of Aggregate Demand Theorists,» Quarterly Journal of Economics 68 (1954): 413.

27 Lionel Rothkrug, Opposition to Louis XIV: The Political and Social Origins of the French Enlightenment (Princeton, NJ: Princeton University Press, 1965). 
IV

\section{CANTILLON'S CIRCLE}

Cantillon's life was one of mystery and secrecy. London and Paris were cities of government spies, informants, and censorship and manipulation of the press. In addition, the bulk of his writings and records were apparently lost in the fire that was designed to cover up his murder. If not for the work of his biographer, Antoin Murphy, ${ }^{28}$ it would be difficult to present anything but a sketch of his life and impossible to paint a clear, comprehensive picture. With this and other information we will sketch an outline of some of the important people in Cantillon's life and construct the possibility of his intellectual circle.

\section{James Brydges}

Cantillon served as a clerk in the office of assistant Paymaster General in Spain during the War of Spanish Succession. James Brydges was the Paymaster General for England and is considered to be the most successful war profiteer of the times. Cantillon was the young «creative accountant» for Brydges in Spain who made payments to the troops, paid for their provisions, and organized Brydges dealings using two sets of accounting books. All these transactions were subject to commissions for Brydges and one would surmise that provisions were purchased in the market (on Brydges account) and then resold to the military at a much higher price. Cantillon's exposure to war therefore was not one of gallant soldiers and honor, but simply a dishonest way of making money on a grand scale to the determent of the common man. Murphy characterized the system as endemic corruption throughout government:

It must be remembered here that the prevailing moral attitude of early eighteenth-century Britain and France amongst the ruling

28 Antoin E. Murphy, Richard Cantillon: Entrepreneur and Economist (New York: Oxford University Press, 1986). 
class seemed to accept a degree of what twentieth-century observers would categorize as graft and corruption in public office. $^{29}$

Brydges is not included here as an anti-mercantilist, but as a mercantilist and a classic insider. One can only imagine that the young Cantillon was both impressed and repelled at this system of war profiteering. In return for his work and confidence, Brydges helped Cantillon get established with his own bank. Their relationship soured after Brydges lost vast sums in the bubbles to the benefit of Cantillon.

\section{Lord Bolingbroke}

The end of the War of Spanish Succession was achieved with the Treaty of Utrecht under Bolingbroke's direction. The Treaty originally called for free trade between England and France to secure the future peace in the same spirit as Cobden, Bright, and Bastiat. When George I succeeded Queen Anne some Whig politicians who were opposed to Bolingbroke's free trade ideas spread allegations about his Jacobite sympathies. James Brydges suggested to Bolingbroke that he ought to flee the country and sent him and his money to Cantillon in Paris. In addition to cashing Bolingbroke's large bill of exchange, Cantillon invited Bolingbroke to stay in his house and to use his bank as his mailing address. In 1734 when Cantillon was allegedly murdered in London at the height of the Excise Crisis, Bolingbroke was living in the house next door. Murphy is no doubt correct when he suggested that Bolingbrook helped to deepen Cantillon's «innate conservativism.» ${ }^{30}$ As Kramnick noted «Bolingbroke's years in France...solidified his role as one of the important links between French and English ideas at the beginning of the Enlightenment. ${ }^{31}$

29 Murphy, 31.

30 Murphy, 48.

31 Lionel Kramnick, Bolingbroke and His Circle: The Politics of Nostalgia in the Age of Walpole (Ithaca, NY: Cornell University Press, 1968), 14. 
Bolingbroke was a proponent of the landed gentry, or what might be thought of as the physically productive domestic economy. He opposed war and the resulting heavy taxes and national debt that they produced. He was a proponent of free trade, but opposed the monopoly trading companies, along with the «moneyed interests» — a class which was aptly characterized by Murphy:

This class, characterized by its materialistic concern with money and «luxury» expenditure, did not, in Bolingbroke's eyes, generate real wealth and was sucking income away from the gentry as the government taxed the landed class to pay the increasing interest payments on the national debt. The power of the landed class was being eroded by the rise of the financial class. ${ }^{32}$

It was left to Cantillon to create the analytical structure for these views where he built the foundation of the economy upon the independent property owner who must engage with and become mutually interdependent with labor to produce the largest possible output. Money and banking play important, but subsidiary roles, while the market for stocks is generally treated with distain. In later sections of the Essai he showed how national debt and central banks can ruin and throw the state into disorder. As an intimate friend, Bolingbroke is also very important for linking Cantillon to other anti-mercantilists in Paris through his membership in the Club de l'Entresol and possibly in London through the anti-establishment publication, The Craftsman.

\section{Montesquieu}

Murphy reported that Cantillon and his wife were friends of Montesquieu, possibly good friends. ${ }^{33}$ After her husband's murder, Cantillon's wife shortly thereafter married Montesquieu's

\footnotetext{
32 Murphy, 49.

33 Murphy, 200.
} 
best friend, Francois Bulkeley, a French military officer who had become a spy for the British government to remedy his personal financial problems. Shackleton noted that there is the possibility of a strong influence of Cantillon on the commerce chapters in the Spirit of the Laws. ${ }^{34}$ Montesquieu was of course long inclined to anti-mercantilist views so that, as Devletoglou has noted, any influence of Cantillon is more likely to be in the technical and theoretical areas of economics. ${ }^{35}$ Therefore we can speculate that there is some possibility that Montesquieu read the Essai.

For our purpose however influence and intimacy are not as important as mere connection and similarity of economic views. The broader purpose here is simply to connect the two and show that they have similar «outsider» anti-mercantilist views. Cantillon and Montesquieu held similar economic views and it seems clear that Montesquieu's views were that of an outsider and antimercantilist. Montesquieu was the most widely quoted writer on government in Revolutionary America. His Persian Letters mocks certain aspects of French society, culture, government and religion from «literally» an outsider's perspective of a Persian in Paris. His Considerations on the Causes of the Grandeur and Decadence of the Romans examined the great question facing France through the history of Rome. Finally, his The Spirit of the Laws is his attempt to solve the problems facing France by showing that only a return to the true spirit of law could make France avert the problems it faced. Montesquieu showed that a society's government must be such that people are protected from other people and their government. The book was banned by the Church and he was widely attacked for his views. Montesquieu was in most respects an anti-mercantilist and was a member of the Club de l'Entresol.

34 Robert Shackleton, Montesquieu: A Critical Biography (London: Oxford University Press, 1961), 135, n.2.

35 Nicos E. Devletoglou, «Montesquieu and the Wealth of Nations,» Canadian Journal of Economics and Political Science 29 (1963): 1-25. 


\section{Club de 1'Entresol}

Abbé Alary established the Club de l' Entresol in the early 1720s with its membership drawing heavily on the Matignon family circle and included Lord Bolingbroke. Members gathered for weekly meetings in Alary's Paris apartment a few blocks from Cantillon's bank to exchange information, discuss politics, government, and foreign affairs, and to present and critique their own original works. Cantillon's social status would have precluded him from being a member, but Bolingbroke's friendship did create a nexus by which Cantillon could be introduced to the intelligentsia of Paris. According to Murphy:

Bolingbroke was in a position to introduce Cantillon to friends such as the Abbé Alary, Boulainvilliers, Levesque de Pouilly, Montesquieu, and Voltaire. In France, Bolingbroke mixed in influential circles and courted the intelligentsia of the time. We know that later on in the 1720s Cantillon and his wife were good friends of Montesquieu, though we are not in a position to determine exactly when this friendship started. Cantillon also probably met Voltaire through their mutual friendship with Nicolas Thiériot, one of Voltaire's cherished friends. Cantillon seems to have been at home with the literati and intellectuals of the day. ${ }^{36}$

While club members represented a diversity of opinion its leading members placed great emphasis on some of the major tenets of anti-mercantilism such as free trade, tax reform, and opposition to war and national debt. ${ }^{37}$ Shackleton described the club as one of the most interesting organizations in eighteenthcentury France: «They flung themselves...into acutely controversial political, social, and historical problems; and some apparently innocuous themes were in reality pregnant with danger.» 38

36 Murphy, 48.

37 Childs, A Political Academy in Paris, 1724-1731: The Entresol and its Members (Oxford: Voltaire Foundation, 2000), chapters $9 \& 10$.

38 Shackleton, 63. 
Abbé Alary, the founder and President of the Club was the protégé of Louis Du Four, the Abbé de Longuerue, who was himself a protégé of Fénelon, the great anti-mercantilist. He later became the protégé of the Abbé de Dangeau who had some influence at the royal court and thus Alary became attached to the Duc du Maine faction (the center of opposition to the Regent) at the end of the reign of Louis XIV. There he met Lord Bolingbroke and the Marquis de Torcy, the engineers of the Treaty of Utrecht. Briggs noted that this opened Alary to a wide class of notable people and established a life long intellectual friendship with Bolingbroke on the general question of the encroachment of government upon liberty. ${ }^{39}$

In what can only be described as an incredible reversal of fortune, Alary who was on the verge of being sent to the Bastille, soon thereafter became the tutor of young Louis $\mathrm{XV}$, after which he became a man of means and high society and was made Assistant at the Royal Library and a member of the French Academy. He founded the Club de l'Entresol in the early 1720s and saw the Club become influential in Paris only to be disbanded in 1731 by Cardinal Fleury who thought the Club was undermining the government.

The work of the Marquis de Lassay represents the transition of the seventeenth century ideas of Fénelon to the Enlightenment views of Montesquieu. Briggs reported that Lassay believed, for example, that government must rely on militias, not standing armies, the nobility and priesthood should have no unjust privileges, government must be divided and limited, sumptuary laws are unnecessary because luxury goods are not harmful, that there should be free trade and no monopolies, guilds, or tariffs, and taxes should be based on the ability to pay without special exemptions ${ }^{40}$ Lassay is clearly an anti-mercantilist and one who apparently had an impact on Club members, even if he did not become as famous himself as a result.

39 Eric R. Briggs, The Political Academies of France in the Early $18^{\text {th }}$ Century; with Special Reference to the Clubs de L'Entresol, and it its Founder, the Abbé Pierre-Joseph Alary (Cambridge: Trinity College, 1931): 7-24.

40 Briggs, 151-53. 
The Marquis d'Argenson was the chronicler of the Club and according to Seligman was the first writer to employ the phrase laissez faire et laissez passer, the battle cry of anti-mercantilism. ${ }^{41}$ D'Argenson developed a principle found in Lassay's work that government should be united in the monarchy, but that the functions of government should be radically decentralized rather than highly centralized. Local government would collect taxes and representatives would be chosen from all municipal delegates to sit on governing councils. He called for the abolition of venality - the system in pre-Revolutionary France of selling positions in government to the highest bidder- and the privileges of the nobility and argued for restrictions on royal despotism. He also endorsed free trade within the nation and between nations and called for political and academic liberty of thought. Obviously, d'Argenson should be classified as an anti-mercantilist.

Another important member of the Club was the Chevalier Ramsay. He was a Scottish convert to Catholicism and was protégé and biographer of the great anti-mercantilist Fénelon. Ramsey was also a fervent supporter of the Jacobite cause and propagator of free masonry in France. In 1724 Ramsay was chosen to be the tutor to the Pretender James' two sons, Charles Edward and Henry. He was primarily interested and wrote on the topics of religion and philosophy more generally, but according to Childs he is closely associated with anti-mercantilism through Fénelon. ${ }^{42}$ Ramsay wrote letters of introduction for David Hume on his visit to France during 1734-1737 and is a possible conduit connecting Hume with Cantillon's Essai.

Briggs noted that after eight years of existence the Club «had become quite an authority and a factor in public opinion» and in private that club members «freely criticized the government's policies. ${ }^{43}$ He concluded that the purpose of the club had been

41 E.R.A. Seligman, «Review of August Oncken's Die Maxime Laissez faire et laissez passer, ihr Ursprung, ihr Werden. Ein Beitrag zur Geschichte der Freihandelslehre, 1886». Political Science Quarterly 2 (1887): 706-707.

42 Nick Childs, 141

43 Briggs, 184. 
to study government and to determine the principles of good government and then to design reform measures for the «crying abuses of the day.» ${ }^{44}$ Despite their hopes for influence at court, club members were decidedly anti-mercantilist and most were unlikely to receive much sympathy at court. The Club was shut down by Fleury in 1731 due to the belief that the club was spreading antigovernment sentiments. Given that the influential members of the club were anti-mercantilists and that the membership was otherwise dominated by the Matignon family, it seems fair to conjecture that the Club was dominated by anti-mercantilist sympathies. Currently there is no evidence that Cantillon ever attended meetings or that parts of the Essai were read at the club during this crucial juncture between the writing of the Essai around 1730 and the closure of the club in 1731.

\section{$\mathrm{V}$ \\ SUBSEQUENT INFLUENCE}

In addition to possible influences on his contemporaries such as Bolingbroke and Montesquieu it would seem that Cantillon influenced many of the important members of the next generation of anti-mercantilist writers. This was certainly the case in France, but also in England, Scotland, and elsewhere. Some of this influence is known directly from attribution, while in other cases it is less certain. What we can say is that he had a critical impact on the Physiocrats, the Scottish anti-mercantilists, and the French Liberal school and as such he should be considered an important contributor to the French and Scottish Enlightenment -an unrecognized scientific link between the Age of Reason and the Age of Enlightenment.

The Physiocrats were the first distinct school of economics and were clearly anti-mercantilist in their general outlook. They formed in the wake of the publication of Cantillon's Essai in 1755. The Marquis de Mirabeau had a copy of Cantillon's manuscript

\footnotetext{
${ }^{44}$ Briggs, 200.
} 
in his possession for sixteen years prior to its publication and he referred to Cantillon in his Ami des hommes au trait de la population which he described as a commentary on Cantillon. Likewise, François Quesnay had read and referenced Cantillon in his article on grain in Diderot's Encyclopédie and his Tableau Économique which was clearly inspired by Cantillon. The meeting of Mirabeau and Quesnay in July of 1757 marks the beginning of the Physiocrats. ${ }^{45}$ The other leader of the Physiocrats was Vincent de Gournay who was an enthusiastic endorser of Cantillon's work, and as Murphy conjectured, de Gournay «was the motivating force behind the publication of the Essai.» ${ }^{46}$ Given the reviews and promotion of Cantillon's work by the leaders of the Physiocrats, the direct impact on their own work, and the fact that a second printing of the Essai was made in 1756, it seems likely that most members of the school would have been wellexposed to Cantillon's economics. As Bloomfield concluded, ever since the rediscovery of Cantillon «the many similarities between his doctrines and those of the Physiocrats have become abundantly clear. ${ }^{47}$

Cantillon's influence is most important with respect to Scotland and the economics of David Hume and Adam Smith. Historians of economic thought have consistently recognized a similarity between Cantillon and David Hume's three unique contributions to economics (the price-specie flow mechanism, the distinction between positive and normative economics, and the short-run effect of increases in the money supply on output and employment). By placing Hume within the anti-mercantilist intellectual circle of Cantillon during the years 1734-1737 we can infer that Hume in all likelihood read a copy of Cantillon's manuscript. The connection between Cantillon and Adam Smith is easily established because he is referred to in the Wealth of Nations. Furthermore, scholars have recognized the influence of Cantillon on Smith on a variety of

45 Henry Higgs, The Physiocrats: Six Lectures on the French Économistes of the $18^{\text {th }}$ Century (New York: The Macmillan Company, 1897): 19-25.

46 Murphy, 308.

47 Arthur I. Bloomfield, «The Foreign-Trade Doctrines of the Physiocrats,» American Economic Review 28 (1938): 716-735. 
microeconomic concepts like competition and wage differentials. We can now even suggest that Cantillon's model of the isolated estate provided the theoretical superstructure for Smith's concept of the invisible hand. Thus Hume and Smith, the two great pillars of Scottish anti-mercantilism, were both strongly influenced by Cantillon's economics.

It would seem that the French Liberal School was also heavily influenced by Cantillon both directly and indirectly through the influence of the Physiocrats. Turgot mentions Cantillon in his diary and his economics clearly shows a heavy influence from Cantillon especially in the areas of price theory, monetary economics and the role of the entrepreneur. Étienne Bonnot de Condillac and his brother Gabriel Bonnot de Mably both refer to Cantillon in their works. ${ }^{48}$ Condillac's Commerce and Government: Considered in their Mutual Relationship appears to have been heavily influenced by Cantillon throughout. Condillac referenced Cantillon twice on the technical matters of the relative cost of Belgian lace and the amount of money that exists in a state. He noted that «I have drawn the basis of this chapter from this work (the Essai), and several observations of which I have made use in other chapters. It is one of the best works I know on this subject.» ${ }^{49}$ Finally, J. B. Say, who although he comes from a latter period, is still heavily influenced by Cantillon. Schumpeter has established that Say was influenced by Quesnay, the Physiocrats, Turgot, and Condillac. Salerno has established that although Say is often referred to as the French Adam Smith, his methodology was strictly that of Cantillon, and that Say condemned Smith in the area of methodology. Of course, the French Liberals were antimercantilists. ${ }^{50}$

At this time Cantillon's influence in England seems less pronounced. Surely his nephew Philip Cantillon borrowed from

48 See Higgs (1931, Appendix B)

49 Étienne Bonnot, Abbé de Condillac, Commerce and Government: Considerations in their Mutual Relationship. Eds. Shelagh Eltis and Walter Eltis (Northampton, MA: Edward Elgar. 1997: 134).

50 Joseph T. Salerno, «Influence of Cantillon's Essai on the Methodology of J.B. Say: A Comment on Liggio,» Journal of Libertarian Studies 7 (1985): 305-316. 
the Essai for his Analysis of Trade and Postlethwayt borrowed liberally for his A Dissertation on the Plan, Use and Importance of the Universal Dictionary of Trade and Commerce and Great Britain's True System, etc. Jevons also attributed a very strong influence of Cantillon on Joseph Harris's An Essay Upon Money and Coins. These works could be classified as anti-mercantilist, although Postlethwayt was anything but a committed anti-mercantilist. In this sense Cantillon might be seen as influencing what Grampp described as the «liberal elements» in English mercantilism. ${ }^{51}$

The totality of evidence presented here is that Cantillon had significant influence on many of the important writers from the next generation of anti-mercantilists, including the Physiocrats, the Scottish anti-mercantilists, and the French Liberals. This finding gives us greater confidence in the overall proposition that Cantillon was an anti-mercantilist.

\section{VI}

\section{SUMMARY AND CONCLUSIONS}

This investigation results in the important if not startling conclusion that Cantillon is possibly best viewed as an anti-mercantilist. Also important is that it demonstrates the important role that history played in the development of economic ideas. By linking the early French anti-mercantilists with Cantillon and his circle and later anti-mercantilists such as Adam Smith and Turgot we find that the economic theory developed for the first time in a substantive manner as a response to the mercantile regimes of seventeenth and eighteenth century France and England.

The son of dispossessed landowners from County Kerry Ireland, Cantillon lived and worked on both sides of the wars between the great mercantile powers of England and France. He identified the problems that resulted from this grand struggle and profited from it to become one of the richest private individuals in the world. He is known to or thought to have met and interacted on

51 William D. Grampp, «The Liberal Elements in English Mercantilism,» Quarterly Journal of Economics 66 (1952): 465-501. 
an intellectual level with the great thinkers of his day including Abbé Alary, Lord Bolingbroke, Boulainvilliers, James Brydges (Duke of Chandos), Charles Davenant, John Law, Montesquieu, Sir Isaac Newton, Levesque de Pouilly, Jean Baptiste Rousseau, and Voltaire. In addition to the influential people he met through his banking business and contacts with the Club d'Entresol, it is not unreasonable to speculate that Cantillon came into contact with the likes of English anti-mercantilists such as John Gay, Alexander Pope, Daniel and William Pulteney, and Jonathan Swift in connection with Bolingbroke's work on The Craftsman and his leadership of the opposition leading up to the Excise Crisis of 173334. Notice that with the exception of Brydges, Davenant, Law and Newton - who were all classic insiders - these noteworthy people represented the opposition to the ruling governments in England and France and supported anti-mercantilist policies.

The classification of Cantillon has evolved over time beginning with the label of mercantilist. More modern scholars have tended to question that label and to only endorse a qualified mercantilist identification. Recently, the mercantilist classification has been undermined altogether. The analysis here brings us full circle with the possibility that Cantillon is best seen as an anti-mercantilist. We find his anti-mercantilism primarily in his economic writings where the economy is described as a self-regulating feature of society and where government intervention causes problems on both the microeconomic level (usury laws, prohibitions on exporting gold) and the macroeconomic level (revocation of the Edict of Nantes, monetary manipulation, central banking). His anti-mercantilism is also present in his comments on other writers where mercantilists are ruthlessly criticized, but prominent antimercantilists are politely corrected. His anti-mercantilism can also be found in his "circle," which was composed of the leading anti-mercantilist thinkers of the day. Finally, Cantillon's antimercantilism can be gleaned from the profound impact the Essai had on subsequent anti-mercantilist writers. Essentially, he provided the theory of commerce for what would ultimately become Classical Liberalism.

Anti-mercantilism would have wide-ranging effects in such areas as free trade, peace, anti-slavery, and decolonization, 
including inspiration for the American Revolution and its form of limited government. However, subsequently there was a sharp decline in the advancement of Cantillon-style economics and antimercantilism in general. The Physiocrats fizzled after the death of Quesnay, Turgot was thrown out of office in 1776, Smith entered the tax collectors office in 1778, and the development of economic theory in French Liberal School went into steady decline after Say. Meanwhile other approaches to economics including the British Classicals, Marxism and various forms of socialist thought, along with empirical and formal approaches began to flourish so that by the time Jevons «rediscovered» Cantillon it could be genuinely said that Cantillon had been forgotten. Retracing these steps backward in time is important to understanding the roots of economic theory and the role that it played in our history and to see the role that history played in the development of economics. 